ISSN: $2455-104 X$

DOI: $10.26761 /$ IJRLS.7.2.2021.1392

Volume 7, Issue 2 (April-June) 2021, 8-18, Paper ID: IJRLS-1392

Received: 29 March. 2021 ; Accepted: 15 April. 2021 ; Published: 19 April. 2021

Copyright (๔) 2021 Author(s) retain the copyright of this article. This article is published under the terms of the Creative Commons Attribution License 4.0.

\title{
Assessing Information Communication Technology (ICT) Literacy Skills: A Study of Students of BGS Institute of Technology, Karnataka, India
}

\author{
Shashikala. S. V.1; Dr. Shivakumaraswamy K.N.; \\ Dr. B.K. Narendra ${ }^{3}$
}

Professor, Department of Computer Science and Engineering, B G S Institute of Technology B G Nagara, Nagamangala (Tq), Mandya (Dist) - 571448' ; Librarian, B G S Institute of Technology B G Nagara, Nagamangala (Tq) Mandya (Dist) - 571448²; Principal, B G S Institute of Technology B G Nagara, Nagamangala (Tq) Mandya (Dist) $-571448^{3}$

librarian@bgsit.ac.in

\begin{abstract}
The aim of this study was to assess the information literacy skills of BGS Institute of Technology, Karnataka, India. The used study design in which questionnaire was used to collect data. Altogether 250 questionnaires were distributed proportionally to respondents and 200 were collected with a response rate of $80 \%$. The findings revealed that information sources usage students of BGS Institute of Technology are shown in the table 7.4. The table shows that result among the respondents with regard to the information sources of 'Journal article is a Primary Source' majority of the respondents replied that, 112 (56\%) says 'strongly agree'; only few accounting 4 (2\%) of them state 'strongly disagree' with types of information sources. 7.5. The table shows that the majority of the respondents replied that the preferred format of information sources for 'Electronic format' majority of the respondents scoring, 108 (54\%) say 'agree'; and only 9 (4.5\%) of them say 'disagree' for preferred format of accessing information in BGS Institute of Technology.
\end{abstract}

KEYWORDS: Information Literacy Skills, Assessment, Students of BGSIT, BGS Institute of Technology, Karnataka, India.

\section{INTRODUCTION}

Assessing the information literacy skills in BGS Institute of Technology, Karnataka, India, is playing an important role in BGS Institute of Technology students. Information Literacy (IL) skills, defined as a set of abilities to find when information is needed and have the ability to locate, evaluate, and use the needed information effectively, have emerged around the world as essential skills for the 21 st Century. This is due to the rapid advancement in Information and Communication Technologies (ICT) students are faced with diverse and abundant information choices in their academic studies. This is because information is available in unfiltered formats, raising questions 


\section{Assessing Information Communication Technology (ICT) Literacy Skills: A Study of Students of BGS Institute of Technology, Karnataka, India}

about its authenticity, validity, and reliability. It is a necessary skill that is useful in every aspect of a person's life. For students, information literacy skills would lead to independent and student-oriented learning, rather than dependence on the teacher to provide answers to questions or problems that they encounter.

This in turn creates a greater responsibility towards their own learning, which would help him become dynamic learners and thinkers who are creative, analytical and efficient instead of mere regurgitations of facts. The basic course is a vital component of general education (Cutspec et al., 1999; Morreale et al., 1999), and serves as the cornerstone of the communication discipline (Dance, 2002). Importantly, the basic course provides an ideal environment to teach and assess information literacy, since students apply what they learn about library information through the construction of speeches and presentations. In essence, the opportunity to practice information literacy skills in an applied manner forces student to combine their content knowledge of communication with their library instruction. The two dominant forms of assessment of information literacy skills include the use of short online quizzes, or the assessment of skills as demonstrated in students' assignments. Online quizzes are often favored as universities come under pressure to provide diagnostic and summative assessment of graduate skills (Barrie, 2007). Information has become a factor that enables students at all levels to achieve better teaching and research in universities.

\section{LITERATURE REVIEW}

Davids \& Omar (2018) assess the collaboration between the library and students, and how librarians and students assess the programme. The study used a case study approach. A questionnaire survey asked students to evaluate the implementation of the programme and its impact on users' performance. This study was validated by student's feedback. The information literacy programme was a participatory model, resulting in a shared understanding of information literacy and built strong collaboration between students and librarians. The implications of the study showed that the programme. It is hoped that information literacy will be fully embedded into curricula as stated by the institutional information literacy policy and for it to be part of a fully accredited course.

Andayani (2017) says that, "professional partnership between librarian and faculties in maintaining and publishing the intellectual heritages through the IR. As a new model or innovation of maintaining and publishing, IR is regarded as the complex project. By using descriptive study, the author focuses on the initiative program of the IR development and the roles of the librarian in bridging the self-submission by faculties. It was found that initiated the development of institutional repositories since 2010, and right now has become one of the biggest repositories among the Islamic universities in Indonesia".

Adeleke \& Emeahara (2016) relationship between information literacy and the use of electronic information resources, the study adopted a descriptive survey design. Data were analyzed using descriptive statistical methods percentages, mean, standard deviation, analysis of variance, correlation analysis and regression analysis. There was a significant relationship between information literacy skills and use of electronic information resources at $\mathrm{a}=0.05$ $(\mathrm{P}=0.34$ ). Information and Communication Technology (ICT) course is part of the curriculum of every postgraduate programme, with emphasis on e-information literacy.

Haji \& et.al (2014) examine the current and future of information literacy programs, the role of university libraries in promoting it. Author conducted in three universities of Zanzibar, The authors show that a certain degree of IL awareness exists among library and academic staff, though promotion and provision of its skills are still in the infancy stages. The researchers made a number of recommendations to address the shortcomings, organize information literacy seminars and workshops, create awareness programs, design and implement information literacy curriculum and course content. 
Kpebor \& Emojorho (2012) towards understanding the prior information literacy knowledge of first year students at the University of Benin, and implications for how librarians understand readiness for library research as well as for the future development of information literacy programs at the secondary school level. Lack of understanding of prior knowledge of university libraries is in itself a barrier to engaging students in the research process in their first year, as it may result in programs that do not inspire students. A questionnaire was designed and administered at the point of student's library registration. The author says that students do not teach information literacy skills from secondary schools and they have little knowledge of information literacy skills.

Lockhart (2011) highlights the challenges and opportunities presented during the process, the author says of a mini information literacy audit conducted in CPUT to gauge how faculties were responding to the policy guidelines. It was also important to identify the gaps and work on strategies to address those. These strategies will be discussed. Furthermore the paper also outlines how an Online Information Literacy Module has been developed and how it is used by various academics in the institution to enrich and enhance their IL curriculum. Lastly the author presents information on how the library uses the institution's eLearning platform, Blackboard, to administer tests for various lecturers who make use of this online module.

\section{PURPOSE OF THE STUDY}

The purpose of this study was to assess information literacy skills of students in B G S Institute of Technology, Karnataka, India.

\section{SPECIFIC OBJECTIVES OF THE STUDY}

The study sought to achieve the following specific objectives:

1. To identify knowledge of students of different types of information sources.

2. To know the purpose for which students use and access information.

3. To determine how students cited and referenced information sources.

4. To find out the students familiarity with citation and reference management software tools.

\section{SCOPE AND LIMITATION}

The scope of study Information accessing information literacy skills of students of B G S Institute of Technology, Karnataka, India. Geographically the coverage of the BGS Institute of Technology students in the study.

\section{METHODOLOGY AND SURVEY DESIGN}

The present study started with literature search from Library and Information Science Abstract (LISA) and Library and Information Science and Technology Abstract (LISTA) database, Google Scholar, and Emerald Insight. Some important books published by American Library Association (ALA) were also consulted to design the questionnaire. A well design questionnaire was distributed to BGSIT Students, in Karnataka state, India.

\section{RESULTS AND DISCUSSIONS}

Preliminary questions in the survey sought to gather teaching students' demographics. Responses to these questions are presented in the multi variable below.

\subsection{Awareness of Information Sources}

The respondents were asked to indicate whether they were aware of information sources. A total of 200 BGS Institute of Technology students responded to this question and the results are presented in table 7.1. The majority of 


\section{Assessing Information Communication Technology (ICT) Literacy Skills: A Study of Students of BGS Institute of Technology, Karnataka, India}

the respondents are scoring $182(91 \%)$ of the respondents were aware of information sources and very few accounting 18(9\%) indicated that there were not aware with information sources.

Table 7.1Awareness of Information Sources

\begin{tabular}{|l|l|c|c|}
\hline S/N & Awareness & No. of Responses & Percentage \\
\hline 1 & Yes & 182 & 91 \\
\hline 2 & No & 18 & 9 \\
\hline \multicolumn{2}{r|}{ Total } & $\mathbf{2 0 0}$ & $\mathbf{1 0 0 . 0 0}$ \\
\hline
\end{tabular}

Awareness of Information Sources

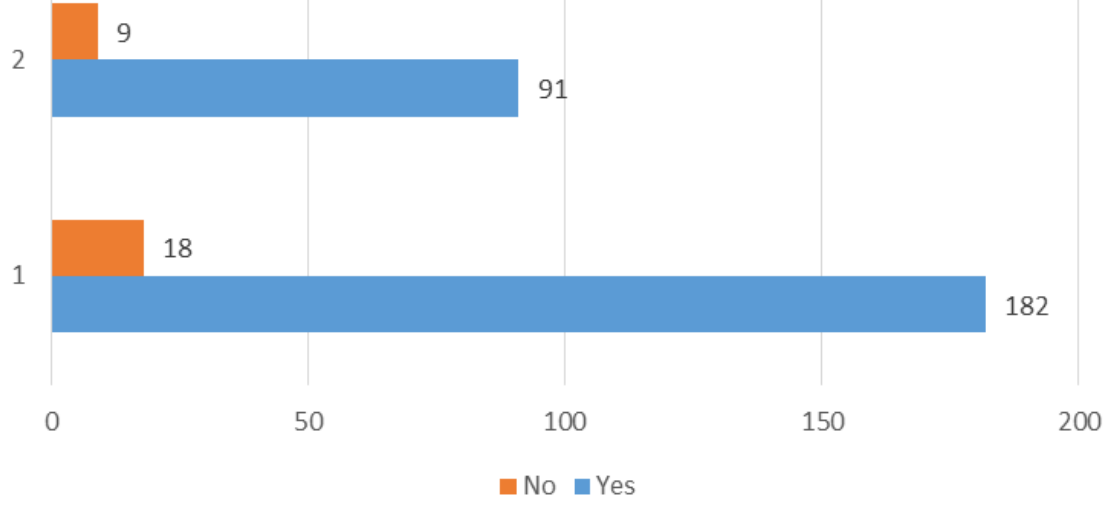

Fig: Awareness of Information Sources

\subsection{Types of information sources.}

There are various types of information sources such as A Textbook is a Secondary Source; A Dictionary is a Tertiary Source; journal article is a Primary Source; A Manuscript is a Primary Source; Study and teaching material Secondary Source; Manuals/Guide books is a Tertiary Source.

Table 7.2 Types of information sources

\begin{tabular}{|c|c|c|c|c|c|c|c|}
\hline \multirow{2}{*}{$\mathbf{S} / \mathbf{N}$} & \multirow{2}{*}{ Information Sources } & \multicolumn{5}{|c|}{ Responses in Percentage $(\mathrm{N}=\mathbf{2 0 0})$} & \multirow{2}{*}{$\begin{array}{c}\text { Percent } \\
\text { age }\end{array}$} \\
\hline & & 1 & 2 & 3 & 4 & 5 & \\
\hline 1 & A Textbook is a Secondary Source. & $\begin{array}{c}6 \\
(3)\end{array}$ & $\begin{array}{l}14 \\
(7)\end{array}$ & $\begin{array}{c}32 \\
(16)\end{array}$ & $\begin{array}{c}68 \\
(34)\end{array}$ & $\begin{array}{c}80 \\
(40)\end{array}$ & $\begin{array}{c}200 \\
(100 \%)\end{array}$ \\
\hline 2 & A Dictionary is a Tertiary Source. & $\begin{array}{c}22 \\
(11)\end{array}$ & $\begin{array}{c}26 \\
(18)\end{array}$ & $\begin{array}{c}30 \\
(15)\end{array}$ & $\begin{array}{c}70 \\
(35)\end{array}$ & $\begin{array}{c}52 \\
(26)\end{array}$ & $\begin{array}{c}200 \\
(100 \%)\end{array}$ \\
\hline 3 & Journal article is a Primary Source. & $\begin{array}{c}4 \\
(2)\end{array}$ & $\begin{array}{c}8 \\
(4)\end{array}$ & $\begin{array}{c}20 \\
(10)\end{array}$ & $\begin{array}{c}56 \\
(28)\end{array}$ & $\begin{array}{l}112 \\
(56)\end{array}$ & $\begin{array}{c}200 \\
(100 \%)\end{array}$ \\
\hline 4 & A Manuscript is a Primary Source. & $\begin{array}{l}10 \\
(5)\end{array}$ & $\begin{array}{l}10 \\
(5)\end{array}$ & $\begin{array}{l}14 \\
(7)\end{array}$ & $\begin{array}{c}77 \\
(38.5)\end{array}$ & $\begin{array}{c}89 \\
(44.5)\end{array}$ & $\begin{array}{c}200 \\
(100 \%)\end{array}$ \\
\hline 5 & $\begin{array}{l}\text { Study and teaching material Secondary } \\
\text { Source. }\end{array}$ & $\begin{array}{c}9 \\
(4.5)\end{array}$ & $\begin{array}{c}13 \\
(6.5)\end{array}$ & $\begin{array}{l}10 \\
(5)\end{array}$ & $\begin{array}{l}102 \\
(51)\end{array}$ & $\begin{array}{c}66 \\
(33)\end{array}$ & $\begin{array}{c}200 \\
(100 \%)\end{array}$ \\
\hline 6 & Manuals/Guide books is a Tertiary Source. & $\begin{array}{c}26 \\
(13)\end{array}$ & $\begin{array}{l}18 \\
(9)\end{array}$ & $\begin{array}{r}20 \\
(10)\end{array}$ & $\begin{array}{c}88 \\
(44)\end{array}$ & $\begin{array}{c}48 \\
(24)\end{array}$ & $\begin{array}{c}200 \\
(100 \%)\end{array}$ \\
\hline
\end{tabular}

Key: 1 - Strongly disagree, 2 - Disagree, 3 - Neither agree nor disagree, 4 - Agree, 5 - Strongly agree. 
The analysis of each one of the information sources used by the respondents is presented in table 7.2, those students' respondents who indicated strongly disagree to agree, a follow-up question was asked to match examples of information materials into primary, secondary and tertiary sources. 200 students of B G S Institute of Technology responded to this questions. 7.2. The table shows that result among the respondents with respect to the information sources of 'A Textbook is a Secondary Source' many respondents scoring 80 (40\%) say 'strongly agree' and few accounting of respondents are scoring $6(3 \%)$ of them say 'strongly disagree'; among the respondents with respect to the information sources of 'A Dictionary is a Tertiary Source'. Respondents scoring 70 (35\%) say 'agree' and only $22(11 \%)$ of them say 'strongly disagree'. Similarly, among the respondents with regard to the information sources of 'Journal article is a Primary Source' majority of the respondents replied that, 112 (56\%) says 'strongly agree' and only few accounting 4 (2\%) of their state 'strongly disagree'. With regard to the information sources of 'A Manuscript is a Primary Source'. Maximum respondents are scoring 89 (44.5\%) say 'strongly agree' and 10 (5\%) of them say 'strongly disagree'. Similarly, among the respondents with regard to the information sources of 'Study and teaching material Secondary Source' majority of the respondents scoring, 102 (51\%) says 'agree' \& only 9 (3\%) of their state 'strongly disagree'. The last parameter of information sources of 'Manuals/Guide books is a Tertiary Source'. Many respondents are numbering 88 (44\%) say 'agree', and 18 (9\%) of them say 'disagree' with types of information sources.

\subsection{Preferred Formats for Accessing Information.}

The Adichunachanagiri University needs to preferred formats of information sources in the appropriate media to support formal and informal learning processes. It should also help the user to make use of these learning resources effectively as well as providing facilities that enable people to study. The BGSIT library has both print and non-print collections to meet the information requirement of all categories of users. An attempt is made here to know the use of BGSIT college students towards preferred formats of accessing information. The analysis of each one of the preferred format of information sources used by the respondents is presented in table 7.3. The table shows that the majority of the respondents replied that the preferred format of information sources 'Print Format', scoring 85 (42.5) say 'agree' and few accounting scoring $8(4 \%)$ of them say 'strongly disagree' with accessing information. Observed from the responses for 'Electronic format' majority of the respondents scoring, 108 (54\%) say 'agree'; and only 9 $(4.5 \%)$ of them say 'disagree'.

Table 7.3 Preferred Format of Information Sources

\begin{tabular}{|c|c|c|c|c|c|c|c|}
\hline \multirow[t]{2}{*}{$\mathbf{S} / \mathbf{N}$} & \multirow{2}{*}{$\begin{array}{l}\text { Preferred Format of } \\
\text { Information Sources }\end{array}$} & \multicolumn{5}{|c|}{ Responses in Percentage $(\mathrm{N}=200)$} & \multirow[t]{2}{*}{ Percentage } \\
\hline & & 1 & 2 & 3 & 4 & 5 & \\
\hline 1 & Print Format. & $\begin{array}{l}8 \\
(4)\end{array}$ & $\begin{array}{c}25 \\
(12.5)\end{array}$ & $\begin{array}{l}12 \\
(6)\end{array}$ & $\begin{array}{c}85 \\
(42.5)\end{array}$ & $\begin{array}{c}70 \\
(35)\end{array}$ & $\begin{array}{c}200 \\
(100 \%)\end{array}$ \\
\hline 2 & Electronic format. & $\begin{array}{l}12 \\
(6)\end{array}$ & $\begin{array}{c}9 \\
(4.5)\end{array}$ & $\begin{array}{c}32 \\
(16)\end{array}$ & $\begin{array}{l}108 \\
(54)\end{array}$ & $\begin{array}{c}39 \\
(19.5)\end{array}$ & $\begin{array}{c}200 \\
(100 \%)\end{array}$ \\
\hline 3 & Both. & $\begin{array}{l}4 \\
\text { (2) }\end{array}$ & $\begin{array}{c}9 \\
(4.5)\end{array}$ & $\begin{array}{c}5 \\
(2.5)\end{array}$ & $\begin{array}{c}80 \\
(40)\end{array}$ & $\begin{array}{l}102 \\
(51)\end{array}$ & $\begin{array}{c}200 \\
(100 \%)\end{array}$ \\
\hline
\end{tabular}

Key: 1 - Strongly disagree, 2 - Disagree, 3 - Neither agree nor disagree, 4 - Agree, 5 - Strongly agree. The last parameter of accessing information 'Both' more respondents are numbering 102 (51\%) says 'strongly agree', and only 4 (2\%) of them say 'strongly disagree' for preferred format of accessing information. 


\section{Assessing Information Communication Technology (ICT) Literacy Skills: A Study of Students of BGS Institute of Technology, Karnataka, India}

\subsection{Knowledge of Citation and Referencing Information Sources.}

BGSIT students need to have an understanding of the need for ethical use of various information sources in their academic environment. One of the ways is to adhere to ethics related to fair use of information through proper bibliographical referencing and citation. The respondents were asked about the referencing style(s) they were familiar with in referencing and citing information sources. The analysis of each one of the knowledge of citation and referencing information sources used by the respondents is presented in table 7.4.

Table 7.4 Respondents' Familiarity with Types of Citation and Referencing Styles

\begin{tabular}{|l|l|c|c|c|c|c|c|}
\hline \multirow{2}{*}{ S/N } & Types of bibliographic and referencing & \multicolumn{3}{|c|}{ Responses in Percentage (N=200) } & Percent \\
& style(s) & $\mathbf{1}$ & $\mathbf{2}$ & $\mathbf{3}$ & $\mathbf{4}$ & $\mathbf{5}$ & age \\
\cline { 2 - 7 } 1 & American Psychological Association & 12 & 11 & 17 & 95 & 60 & 200 \\
& (APA). & $(6)$ & $(5.5)$ & $(8.5)$ & $(47.5)$ & $(30)$ & $(100 \%)$ \\
\hline \multirow{2}{*}{2} & Modern Language Association (MLA). & 8 & 15 & 17 & 60 & 100 & 200 \\
& & $(4)$ & $(7.5)$ & $(8.5)$ & $(30)$ & $(50)$ & $(100 \%)$ \\
\hline 3 & ABNT (Brazilian National Standard). & 44 & 32 & 34 & 52 & 60 & 200 \\
& & $(22)$ & $(16)$ & $(17)$ & $(26)$ & $(30)$ & $(100 \%)$ \\
\hline 4 & Vancouver/ICMJE. & 10 & 44 & 26 & 62 & 58 & 200 \\
& & $(5)$ & $(22)$ & $(13)$ & $(31)$ & $(29)$ & $(100 \%)$ \\
\hline 5 & Harvard. & 26 & 18 & 20 & 94 & 42 & 200 \\
& & $(13)$ & $(9)$ & $(10)$ & $(47)$ & $(21)$ & $(100 \%)$ \\
\hline \multirow{2}{*}{6} & Chicago. & 8 & 28 & 18 & 67 & 79 & 200 \\
& & $(4)$ & $(14)$ & $(9)$ & $(33.5)$ & $(39.5)$ & $(100 \%)$ \\
\hline 7 & Oxford. & $(10)$ & $(11)$ & $(15)$ & $(34)$ & $(30)$ & $(100 \%)$ \\
\hline
\end{tabular}

Key: 1 - Strongly disagree, 2 - Disagree, 3 - Neither agree nor disagree, 4 - Agree, 5 - Strongly agree.

Knowledge of citation and referencing information sources used by students of BGS Institute of Technology (BGSIT) is shown in the table 7.4. The table shows that result among the respondents with respect to the of citation and referencing information sources of 'American Psychological Association (APA)' many respondents scoring 95 (47.5\%) say 'agree' and few accounting scoring 11 (5.5\%) of them say 'disagree'; among the respondents with respect to the citation and referencing information sources of 'Modern Language Association (MLA)', the majority of the respondents scoring $100(50 \%)$ say 'strongly agree' and only 8(4\%) of them say 'strongly disagree'. Similarly, with regard to the citation and referencing information sources of 'ABNT (Brazilian National Standard)' respondents replied that, $60(30 \%)$ says 'strongly agree' and only few accounting $32(16 \%)$ of their state 'strongly disagree'. With regard to the citation and referencing information sources of 'Vancouver/ICMJE'. Maximum respondents are scoring $62(31 \%)$ say 'agree' and $10(5 \%)$ of them say 'strongly disagree'. Similarly, among the respondents with regard to the citation and referencing information sources of 'Harvard' majority of the respondents replied that, 94 (47\%) says 'agree' and only 18 (9\%) of their state 'disagree'. Observed from the table 7.4, more number of users replayed to the parameter of 'Chicago' majority of the respondents scoring, 79 (39.5\%) says 'strongly agree' and only $8(4 \%)$ of their state 'strongly disagree'. The last parameter of citation and referencing information sources of 'Oxford' many respondents numbering 68 (34\%) says 'agree', and 20 (10\%) of them says 'strongly disagree' with knowledge of citation and referencing information sources use in BGSIT. 


\subsection{Examples of Unethical Use of Information.}

The respondents of the study use unethical use of information in the BGSIT Library. They are: When a block of text is copied directly, but not enclosed with quotation marks; Handing in an assignment work that has been copied from published sources; Publishing someone else work under his/her own name; Cutting and pasting information from internet without reference to it. This information is shown in table 7.5. The respondents were also asked if they were able to provide an example that could show unethical use of information.

Table 7.5 Examples of unethical use of information

\begin{tabular}{|c|c|c|c|c|c|c|c|}
\hline \multirow{2}{*}{$\mathbf{S} / \mathbf{N}$} & \multirow{2}{*}{$\begin{array}{l}\text { Examples of unethical use of } \\
\text { information }\end{array}$} & \multicolumn{5}{|c|}{ Responses in Percentage $(\mathrm{N}=200)$} & \multirow{2}{*}{$\begin{array}{c}\text { Percen } \\
\text { age }\end{array}$} \\
\hline & & 1 & 2 & 3 & 4 & 5 & \\
\hline 1 & $\begin{array}{l}\text { When a block of text is copied } \\
\text { directly, but not enclosed with } \\
\text { quotation marks. }\end{array}$ & $\begin{array}{c}66 \\
(33)\end{array}$ & $\begin{array}{c}70 \\
(35)\end{array}$ & $\begin{array}{c}34 \\
(17)\end{array}$ & $\begin{array}{l}18 \\
(9)\end{array}$ & $\begin{array}{l}12 \\
(6)\end{array}$ & $\begin{array}{c}200 \\
(100 \%)\end{array}$ \\
\hline 2 & $\begin{array}{l}\text { Handing in an assignment work that } \\
\text { has been copied from published } \\
\text { sources. }\end{array}$ & $\begin{array}{l}86 \\
(43)\end{array}$ & $\begin{array}{c}64 \\
(32)\end{array}$ & $\begin{array}{r}26 \\
(13)\end{array}$ & $\begin{array}{l}14 \\
(7)\end{array}$ & $\begin{array}{l}10 \\
(5)\end{array}$ & $\begin{array}{c}200 \\
(100 \%)\end{array}$ \\
\hline 3 & $\begin{array}{l}\text { Publishing someone else work under } \\
\text { his/her own name. }\end{array}$ & $\begin{array}{l}100 \\
(50)\end{array}$ & $\begin{array}{c}60 \\
(30)\end{array}$ & $\begin{array}{r}20 \\
(10)\end{array}$ & $\begin{array}{c}8 \\
(4)\end{array}$ & $\begin{array}{l}12 \\
(6)\end{array}$ & $\begin{array}{c}200 \\
(100 \%)\end{array}$ \\
\hline 4 & $\begin{array}{l}\text { Cutting and pasting information } \\
\text { from internet without reference to it. }\end{array}$ & $\begin{array}{c}60 \\
(30)\end{array}$ & $\begin{array}{c}44 \\
(22)\end{array}$ & $\begin{array}{c}30 \\
(15)\end{array}$ & $\begin{array}{c}44 \\
(22)\end{array}$ & $\begin{array}{c}22 \\
(11)\end{array}$ & $\begin{array}{c}200 \\
(100 \%)\end{array}$ \\
\hline
\end{tabular}

Key: 1 - Strongly disagree, 2 - Disagree, 3 - Neither agree nor disagree, 4 - Agree, 5 - Strongly agree.

Unethical use of information used by students of BGSIT is shown in the table 7.5. The table shows that result among the respondents with respect to the of unethical use of information of 'When block of text are copied directly but not enclosed with quotation marks.' many respondents scoring 70(35\%) say 'disagree' and few accounting scoring $12(6 \%)$ of them say 'strongly agree'; among the respondents with respect to the unethical use of information of 'Handing in an assignment work that has been copied from published sources' majority of the respondents scoring $86(43 \%)$ say 'strongly disagree' and only $10(5 \%)$ of them say 'strongly agree'. With regard to the unethical use of information of 'Publishing someone else work under his/her own name' majority of the respondents replied that, 100 (50\%) says 'strongly disagree' \& only few accounting $8(4 \%)$ of their state 'agree'. The last parameter of unethical use of information about 'Cutting and pasting information from internet without reference to it' many respondents numbering $60(30 \%)$ says 'strongly disagree', and $11(22 \%)$ of them say 'strongly agree' with the unethical use of information in the BGSIT Library.

\subsection{Importance of Citing and Referencing an Information Source}

The respondents of the study's importance of citing and referencing an information source in the BGSIT Library are as follows: Attribution serves as a fact-checking tool; Citation makes you a better researcher; Good citation practices make you a better writer; a good bibliography shows of your scientific knowledge etc. This information is shown in table 7.6. The respondents were also asked to indicate what they perceived to be a major reason for providing a citation and reference to an information source.

The table shows that result among the respondents with respect to the importance of 'Attribution serves as a factchecking tool' many respondents scoring $90(45 \%)$ say 'agree' and few accounting scoring $10(5 \%)$ of them say 


\section{Assessing Information Communication Technology (ICT) Literacy Skills: A Study of Students of BGS Institute of Technology, Karnataka, India}

'disagree'; among the respondents with respect to the importance of 'Citation makes you a better researcher', more number of the respondents scoring $102(51 \%)$ say 'strongly agree' and only $8(4 \%)$ of them say 'disagree'. Similarly, with regard to the importance of 'Good citation practices make you a better writer' more number of the respondents replied that, 98 (49\%) says 'strongly agree' and only few accounting $2(1 \%)$ of their state 'strongly disagree'. With regard to the importance of 'A good bibliography shows off your scientific knowledge'. Maximum respondents are scoring $85(42.5 \%)$ say 'agree' and $6(3 \%)$ of them say 'disagree'.

Table 7.6 Participants' Responses on Citation and Referencing an Information Source

\begin{tabular}{|c|c|c|c|c|c|c|c|}
\hline \multirow[b]{2}{*}{$\mathbf{S} / \mathbf{N}$} & \multirow{2}{*}{$\begin{array}{l}\text { Reasons for providing citation and } \\
\text { reference to an information source }\end{array}$} & \multicolumn{5}{|c|}{ Responses in Percentage $(\mathrm{N}=200)$} & \multirow{2}{*}{$\begin{array}{c}\text { Percent } \\
\text { age }\end{array}$} \\
\hline & & 1 & 2 & 3 & 4 & 5 & \\
\hline 1 & $\begin{array}{l}\text { Attribution serves as a fact-checking } \\
\text { tool. }\end{array}$ & $\begin{array}{c}13 \\
(6.5)\end{array}$ & $\begin{array}{l}10 \\
(5)\end{array}$ & $\begin{array}{c}17 \\
(8.5)\end{array}$ & $\begin{array}{c}90 \\
(45)\end{array}$ & $\begin{array}{c}70 \\
(35)\end{array}$ & $\begin{array}{c}200 \\
(100 \%)\end{array}$ \\
\hline 2 & $\begin{array}{l}\text { Citation makes you a better } \\
\text { researcher. }\end{array}$ & $\begin{array}{l}10 \\
(5)\end{array}$ & $\begin{array}{c}8 \\
8 \\
(4)\end{array}$ & $\begin{array}{l}14 \\
(7)\end{array}$ & $\begin{array}{c}66 \\
(33)\end{array}$ & $\begin{array}{l}102 \\
(51)\end{array}$ & $\begin{array}{c}200 \\
(100 \%)\end{array}$ \\
\hline 3 & $\begin{array}{l}\text { Good citation practices make you a } \\
\text { better writer. }\end{array}$ & $\begin{array}{c}2 \\
(1)\end{array}$ & $\begin{array}{l}12 \\
(6)\end{array}$ & $\begin{array}{c}8 \\
(4)\end{array}$ & $\begin{array}{c}80 \\
(40)\end{array}$ & $\begin{array}{c}98 \\
(49)\end{array}$ & $\begin{array}{c}200 \\
(100 \%)\end{array}$ \\
\hline 4 & $\begin{array}{l}\text { A good bibliography shows off your } \\
\text { scientific knowledge. }\end{array}$ & $\begin{array}{c}19 \\
(9.5)\end{array}$ & $\begin{array}{c}6 \\
(3)\end{array}$ & $\begin{array}{l}10 \\
(5)\end{array}$ & $\begin{array}{c}85 \\
(42.5)\end{array}$ & $\begin{array}{c}70 \\
(35)\end{array}$ & $\begin{array}{c}200 \\
(100 \%)\end{array}$ \\
\hline 5 & $\begin{array}{l}\text { Careful citation practices will build } \\
\text { your credibility as a scientist or } \\
\text { scholar. }\end{array}$ & $\begin{array}{l}14 \\
(7)\end{array}$ & $\begin{array}{c}9 \\
(4.5)\end{array}$ & $\begin{array}{c}13 \\
(6.5)\end{array}$ & $\begin{array}{c}66 \\
(33)\end{array}$ & $\begin{array}{c}98 \\
(49)\end{array}$ & $\begin{array}{c}200 \\
(100 \%)\end{array}$ \\
\hline 6 & $\begin{array}{l}\text { Citation enables better verification of } \\
\text { your work. }\end{array}$ & $\begin{array}{l}4 \\
(4)\end{array}$ & $\begin{array}{c}24 \\
(12)\end{array}$ & $\begin{array}{c}8 \\
(4)\end{array}$ & $\begin{array}{c}62 \\
(31)\end{array}$ & $\begin{array}{l}102 \\
(51)\end{array}$ & $\begin{array}{c}200 \\
(100 \%)\end{array}$ \\
\hline 7 & $\begin{array}{l}\text { To keep track information sources } \\
\text { used. }\end{array}$ & $\begin{array}{c}20 \\
(10)\end{array}$ & $\begin{array}{l}12 \\
(6)\end{array}$ & $\begin{array}{l}18 \\
(9)\end{array}$ & $\begin{array}{c}55 \\
(57.5)\end{array}$ & $\begin{array}{c}95 \\
(47.5)\end{array}$ & $\begin{array}{c}200 \\
(100 \%)\end{array}$ \\
\hline 8 & $\begin{array}{l}\text { To be honest about one's own } \\
\text { original contribution. }\end{array}$ & $\begin{array}{c}2 \\
(1)\end{array}$ & $\begin{array}{l}6 \\
(3)\end{array}$ & $\begin{array}{c}7 \\
(3.5)\end{array}$ & $\begin{array}{c}77 \\
(38.5)\end{array}$ & $\begin{array}{l}108 \\
(54)\end{array}$ & $\begin{array}{c}200 \\
(100 \%)\end{array}$ \\
\hline 9 & $\begin{array}{l}\text { To protect one from charges of } \\
\text { plagiarism. }\end{array}$ & $\begin{array}{c}17 \\
(8.5)\end{array}$ & $\begin{array}{c}4 \\
(2)\end{array}$ & $\begin{array}{c}5 \\
(2.5)\end{array}$ & $\begin{array}{c}96 \\
(48)\end{array}$ & $\begin{array}{c}78 \\
(39)\end{array}$ & $\begin{array}{c}200 \\
(100 \%)\end{array}$ \\
\hline 10 & $\begin{array}{l}\text { To give credit to those who initiated } \\
\text { the ideas used in the work. }\end{array}$ & $\begin{array}{c}6 \\
(3)\end{array}$ & $\begin{array}{c}21 \\
(10.5)\end{array}$ & $\begin{array}{c}9 \\
(4.5)\end{array}$ & $\begin{array}{c}76 \\
(38)\end{array}$ & $\begin{array}{c}88 \\
(44)\end{array}$ & $\begin{array}{c}200 \\
(100 \%)\end{array}$ \\
\hline
\end{tabular}

Key: 1 - Strongly disagree, 2 - Disagree, 3 - Neither agree nor disagree, 4 - Agree, 5 - Strongly agree.

Observed from the table 7.6, more number of users replayed to the parameter of 'Careful citation practices will build your credibility as a scientist or scholar' majority of the respondents scoring, 98 (49\%) says 'strongly agree' \& only 9 (4.5\%) of their state 'disagree'. Similarly, with regard to the importance of 'Citation enables better verification of your work' majority of the respondents replied that, 102 (51\%) says 'strongly agree' \& only few accounting 4 (4\%) of their state 'strongly disagree'. Observed from the table 7.6, more number of users replayed to the parameter of 'To keep track information sources used' majority of the respondents scoring, 95 (47.5\%) says 'strongly agree'; only $12(6 \%)$ of their state 'disagree'.

Among the respondents with respect to the importance of 'To be honest about one's own original contribution', the majority of the respondents scoring 108 (50\%) say 'strongly agree' and only 2 (1\%) of them say 'strongly disagree'. 
Similarly, with regard to the importance of 'To protect one from charges of plagiarism' maximum of the respondents replied that, $96(48 \%)$ says 'agree'; only few accounting $4(2 \%)$ of them state 'disagree'. The last parameter of importance of 'To give credit to those who initiated the ideas used in the work' many respondents numbering 88 (44\%) say 'strongly agree', and $6(3 \%)$ of them say 'strongly disagree' with the importance of citing and referencing an information source in the students of BGSIT Library.

\subsection{Knowledge of Citation and Reference Management Software Tools.}

The knowledge of citation and reference management software tools among the ACU is shown in table 7.9. There is a range of citation and reference management software tools which are knowing the respondents. They are: Ref Works; Zotero; End Note; Mendeley; and Cite Like. To due to the increasing number of information in digital formats, managing citations and references have become a daunting task for students.

Table 7.7 Participants' Responses on Knowledge of Citation and Reference Management Software Tools.

\begin{tabular}{|l|l|c|c|c|c|c|c|}
\hline \multirow{2}{*}{ S/N } & \multirow{2}{*}{ Responses } & \multicolumn{5}{|c|}{ Responses in Percentage (N=200) } & \multirow{2}{*}{ Percentage } \\
\cline { 3 - 7 } 1 & $\mathbf{1}$ & $\mathbf{2}$ & $\mathbf{3}$ & $\mathbf{4}$ & $\mathbf{5}$ & \\
\hline \multirow{2}{*}{1} & Ref Works. & 44 & 18 & 46 & 60 & 32 & 200 \\
& & $(22)$ & $(9)$ & $(23)$ & $(30)$ & $(16)$ & $(100 \%)$ \\
\hline \multirow{2}{*}{3} & Zotero. & 43 & 21 & 32 & 46 & 58 & 200 \\
& & $(21.3)$ & $(10.5)$ & $(16)$ & $(23)$ & $(29)$ & $(100 \%)$ \\
\hline \multirow{2}{*}{4} & EndNote. & 39 & 28 & 41 & 50 & 42 & 200 \\
& & $(19.5)$ & $(14)$ & $(20.5)$ & $(25)$ & $(21)$ & $(100 \%)$ \\
\hline \multirow{2}{*}{5} & Mendeley. & 14 & 7 & 24 & 85 & 70 & 200 \\
& & $(7)$ & $(3.5)$ & $(12)$ & $(42.5)$ & $(35)$ & $(100 \%)$ \\
\hline
\end{tabular}

Key: 1 - Strongly disagree, 2 - Disagree, 3 - Neither agree nor disagree, 4 - Agree, 5 - Strongly agree.

However, currently many reference management software tools exist in the market either freely or commercially. These software tools used by scholars to electronically store, organize and format references and citations within the manuscript. Therefore, another objective was sought from respondents if they were aware of and able to use some of the bibliographic and reference management software tools.

The table shows that result among the respondents with respect to the citation and reference management software tools of 'RefWorks' respondents are scoring 60 (45\%) say 'agree' and few accounting scoring 18 (9\%) of them say 'disagree'; among the respondents with respect to the citation and reference management software tools of 'Zotero' respondents scoring 58 (29\%) say 'strongly agree' and 21 (10.5\%) of them say 'disagree'. Similarly, with regard to the citation and reference management software tools of 'End Note' majority of the respondents replied that, 50 (42.5\%) says 'agree' \& only few accounting 28 (14\%) of them state 'disagree'. Observed from the table 7.9, more number of users replayed to the parameter of 'Mendeley' majority of the respondents scoring, 85 (42.5\%) says 'agree'; only 7 (3.5\%) of their state 'disagree'. The last parameter of importance of 'CiteULike' many respondents numbering $62(31 \%)$ says 'agree', and $12(6 \%)$ of them say 'disagree' with the knowledge of citation and reference management software tools in the students' BGSIT Library. 


\section{Assessing Information Communication Technology (ICT) Literacy Skills: A Study of Students of BGS Institute of Technology, Karnataka, India}

\section{CONCLUSION, FINDINGS AND RECOMMENDATIONS}

The purpose of this study was to assess information literacy skills of students at B G S Institute of Technology (BGSIT), Karnataka, India. . The study has shown that ILS (information literacy skills) at the BGSIT demonstrates a high level of awareness of types of information sources, though awareness did not translate into actual usage. The students also demonstrated high deficiency in identifying diverse information sources, including their uses which is an indication that they possessed moderate IL skills on types of information sources. It can be concluded that IL training might have lacked adequate hands-on experiences. On ethical use the information, the study established that the sampled Education students at the BGSIT expressed familiarity with using APA reference style. This could be attributed to the fact that APA seems to be a recommended referencing style at the BGSIT. They also expressed awareness of the importance of providing citations and references to academic work to avoid plagiarism. This was quite encouraging. Despite the positive indications, the majority of the students demonstrated deficient knowledge on writing proper citation and references. They also did not know the bibliographic and reference management software tools. This meant that students might have lacked hands-on experience and also the IL instruction might not have been incorporated other referencing styles including reference management software tools.

Findings: (1). Knowledge of citation and referencing information sources used by students of B G S Institute of Technology (BGSIT) is shown in the table 7.4. The table shows that result among the respondents with respect to the of citation and referencing information sources of 'Modern Language Association (MLA)', the majority of the respondents scoring $100(50 \%)$ say 'strongly agree' Knowledge of MLA citation and referencing information sources. (2). The respondents of the study's importance of citing and referencing an information source in the BGSIT Library, the table 7.6, shows that result among the respondents with respect to the importance of 'To be honest about one's own original contribution', the majority of the respondents scoring $108(50 \%)$ say 'strongly agree' with the importance of citing and referencing an information source in the students of B G S Institute of Technology (BGSIT). (3). Knowledge of citation and reference management software tools among the BGSIT is shown in table 7.7. More number of users replayed to the parameter of 'Mendeley' majority of the respondents scoring, 85 (42.5\%) says 'agree' with importance of citing and referencing an information source in the students' BGSIT Library.

Recommendations: Therefore, based on the above findings the study makes the following recommendations: Librarians as custodians of knowledge should conduct advocacy and awareness of emerging technologies and incorporate to IL programmes in B G S Institute of Technology (BGSIT). This will spur interest among the students to participate in different IL programs available at the B G S Institute of Technology. Library administrators should also provide enough hands-on experience to students rather than focusing on theoretical concepts only. The BGSIT should also improve the network connectivity by increasing its bandwidth. The availability of such facilities will ensure conducive environment for teaching and learning and enable the students have more time to conduct practical sessions and eventually improves their IL skills. This will further lead to effective use of information resources.

\section{REFERENCES}

[1] Abubakar, D., \& Chollom, K. M. (2017). Relationship of User Education, Computer Literacy and Information and Communication Technology Accessibility and Use of E-Resources by Postgraduate Students in Nigerian University Libraries. Library Philosophy \& Practice, 13-42.

[2] Adeleke, D. S., \& Emeahara, E. N. (2016). Relationship between Information Literacy and Use of Electronic Information Resources by Postgraduate Students of the University of Ibadan. Library Philosophy \& Practice, 1-16. 
[3] Andayani, U. (2017). The Collaboration between Librarians and Faculties in Preserving and Publishing the Intellectual Heritages through the Institutional Repositories: a Case at Syarif Hidayatullah State Islamic University, Jakarta. Library Philosophy \& Practice, 1-12.

[4] Barrie, S. (2007). A conceptual framework for the teaching and learning of generic graduate attributes. Studies in Higher Education, 32(4), 439-458.

[5] Dance, E. X. (2002). Speech and thought: A renewal. Communication Education, 51, 355-359.

[6] Davids \& Omar (2018) Davids, Z., \& Omar, Y. (2018). Implementing a Certificate of Information Literacy Programme and engaging with faculty: a case study of the Cape Peninsula University of Technology. South African Journal of Libraries \& Information Science, 84(1), 1-10.

[7] Davids, Z., \& Omar, Y. (2018). Implementing a Certificate of Information Literacy Programme and engaging with faculty: a case study of the Cape Peninsula University of Technology. South African Journal of Libraries \& Information Science, 84(1), 1-10.

[8] Davids, Z., \& Omar, Y. (2018). Implementing a Certificate of Information Literacy Programme and engaging with faculty: a case study of the Cape Peninsula University of Technology. South African Journal of Libraries \& Information Science, 84(1), 1-10.

[9] Haji, H. A., Mwitumbe, K. H., \& Omar, A. M. (2014). Information literacy in Zanzibar universities: Current situation and the way forward. IFLA Journal, 40(4), 280-288.

[10] Kpebor, C. O., \& Emojorho, D. (2012). Information Literacy Skills: A Survey of the Transition of Students from Secondary to University Education in Edo State, Nigeria. Library Philosophy \& Practice, 1-9.

[11] Lockhart, J. (2011). The Before and After of an Information Literacy Policy at the Cape Peninsula University of Technology (Cput). IATUL Annual Conference Proceedings, 21, 1-10.

[12] Malanga, D. F. (2017). Assessing Information Literacy Skills: A Survey of Undergraduate Education Students at the University of Livingstonia in Malawi. Library Philosophy and Practice (e-journal), 1806.

[13] Morreale, S. P., Hanna, M. S., Berko, R. M., \& Gibson, J. W. (1999). The basic communication course at U.S. colleges and universities: VI. Basic Communication Course Annual, 11, 1-36.

[14] Neerputh, S. (2016). Integrating Information Literacy in the General Education Module at the Durban University of Technology, South Africa. Mousaion, 34(1), 43-55.

[15] Turnbull, B., Royal, B., \& Purnell, M. (2011). Using an interdisciplinary partnership to develop nursing students' information literacy skills: An evaluation. Contemporary Nurse: A Journal for the Australian Nursing Profession, 38(1-2), 122-129. 